\title{
Transatlantic Relations and Lithuania: Unfinished Issues of Security
}

The present article deals with the problem, often discussed in the public sphere, of the decreased attention that the USA gives to Lithuania and to the region of Central and Eastern Europe (CEE) on the whole, discusses the changing international environment, USA's "pivot to Asia" and possible changes in the US foreign policy during the time of President Obama's second term of office. The article states that Lithuania, being interested in the vitality of transatlantic relations, should consider the issue of "winning back" the USA's attention to the region and to Europe as a whole, by assessing the issues of security to be solved. The research shows that even with a decade of its membership in Euro-Atlantic structures, Lithuania has not been fully integrated into the transatlantic security community. On the basis of a theoretical perspective of a small state and neoclassical realism, the article deals with the external and internal factors explaining the state's foreign policy, analyzes Lithuania's possible behavior in an international space, including the North Atlantic Alliance. In recent years NATO has been confronted not only with the global threats of the 21 st century but also with a "burden share" problem that is becoming ever more acute. The situation of Lithuania's security as to the guarantees of collective defense provided by the Alliance is assessed as the best one since the restoration of Independence; however, this does not release it from the necessity to widely develop its own defense capacities. Even though Europe constantly underlines the importance of transatlantic relations and intensive economic-trade relations with the USA, it has not developed a common attitude to its relations with the USA. Taking into consideration the present-day challenges, Europe needs a more global, more strategic attitude.

\section{Introduction}

Opinions about the decreased attention that the USA gives to the region of Central and Eastern Europe (hereinafter referred to as CEE), hence, to Lithuania too, have recently been often heard in the public sphere ${ }^{1}$. These apprehensions are provoked by the changed plans of the USA concerning the

\footnotetext{
* Sigita Trainauskiene is a doctoral student of the Faculty of Social Sciences of Kaunas University of Technology. Address for correspondence: K. Donelaičio 20-508, LT-44239 Kaunas, Lithuania, tel. +37037-300144, e-mail: sockat@ktu.lt

1 "An Open Letter to the Obama Administration from Central and Eastern Europe," RFE/RL, July 16, 2009; Bugajski J., ”Unintended Consequences: Impact on the U.S. - Russia Détente On the Wider Europe “, Lithuanian Foreign Policy Review 24, 2010, p. 9-22; Lopata R., "The Lithuanian-American Association: Why Do We Need the US?', Lithuanian Foreign Policy Review 23, 2010, p.111-112
} 
anti-missile defense system in Eastern Europe and by the supposition that after the USA policy with respect to Russia has changed (having replaced "containment" by "engagement") outspoken "soft power" expansionistic moods in Russia will strengthen therefore its neighbors will possibly become more vulnerable. However, there are opinions that the concern of the Baltic Sea eastern region about Washington's commitment to security stability of the countries of this region is groundless, and the CEE states "should support USA's aspiration to restore its relations with Russia though success is not guaranteed"2.

This discussion testifies to the fact that security problems in the region remain acute despite the fact that Lithuania, like other countries of the region, is a member of NATO, which is committed to permanent collective defense (24 hours per day, 7 days per week, 365 days per year ${ }^{3}$ ). On the one hand, Lithuania's present position in the international security system has been the best one since the restoration of Independence; on the other hand, the national Security Strategy of the Republic of Lithuania identifies certain external and internal risk factors and threats to national security (recently the problem of energy security has been especially emphasized), the necessity to successfully establish oneself in Euro-Atlantic structures ${ }^{4}$ and to go on strengthening the transatlantic relation is further considered; the academic discussion about the tendencies of "securitizing" its foreign policy, e.g. with respect to Russia, continues. ${ }^{5}$

Lithuania's concern about national security and transatlantic partnership, looking at it from the perspective of a small state and bearing in mind historical experience, is quite understandable. The political and academic elite of Lithuania, in essence, unanimously recognize the exceptional role of the USA in restoring the independent state of Lithuania and regard it as "the main guarantee of Lithuania's self-efficacy". US-Lithuanian ties are characterized as a strategic partnership ${ }^{7}$, which is determined by ideological, geopolitical and political circumstances, therefore Lithuania is especially

\footnotetext{
${ }^{2}$ Krickus D., "Barack Obama and Security In the East Baltic Sea Region", Lithuanian Annual Strategic Review, 2010-2011, vol. 9, p. 9.

${ }^{3}$ Secretary General welcomes Lithuanian leadership and commitment, February 1, 2013, http://www.nato. int/cps/en/SID-D047024D-A5B7A679/natolive/news_94378.htm, 01022013

${ }^{4}$ The National Security Strategy of the Republic of Lithuania, 2012, XIP-3399(2), Programme of the 15th Government, 2008, XI-52

${ }_{5}^{5}$ E.g., Statkus N., Paulauskas K., Tarp geopolitikos ir postmoderno: kur link sukti Lietuvos užsienio politikai? [In Between Geopolitics and Postmodernism: What Direction the Lithuanian Foreign Policy Take?], Vilnius, 2008; also Works by T. Janeliūnas, G. Miniotaitè and others ${ }^{6}$ Lopata R., Kodèl mums, lietuviams, reikalinga Amerika? [Why do we, Lithuanians, need America?] http://www.bavi.lt/r-lopata-kodel-mums-lietuviams-reikalinga-amerika/, 12092012

${ }^{7}$ See for more: The Programme of the 15th Government of the Republic of Lithuania, 2008; The national Security Strategy of the republic of Lithuania, 2012, XIP-3399(2)
} 
sensitive to the changes in the US foreign policy. Vaidotas Urbelis and Gerda Jakštaite have analyzed US-Lithuanian relations, and they draw attention to the fact that the significance of Lithuania as a small country with respect to the USA manifests itself within the CEE or the Nordic-Baltic context only ${ }^{8}$. During the past years, to balance the policy of "reset" the CEE countries sought reassurance that the USA remained committed to the region's security, or, as Poland, tried to "reset" their relationships with Russia themselves. Nonetheless, in the analysts' opinion the countries of the CEE region were not so much affected by the fear of the "new Yalta" or doubts about the political will of NATO; rather, they felt the absence of a clear vision of the US policy in that region ${ }^{9}$ as the factor that united and stabilized the foreign policy of the countries of the region.

However, having achieved Lithuania's membership in NATO and the European Union, which is regarded as a historical achievement, a certain vacuum in foreign policy is observed; hence there are attempts to fill it with a different substance. Perhaps the most obvious attempt to define a new post-integration concept of foreign policy was made in a speech by Artūras Paulauskas, interim and acting President of the Republic of Lithuania delivered at Vilnius University in $2004^{10}$. This, however, was the beginning rather than the end of the discussions. According to Evaldas Nekrašas, after a direct existential threat to the Lithuanian state had disappeared, Lithuania should have given the same significance to the issues of welfare of the state and its citizens ${ }^{11}$, chosen the policy of the West rather than that of the East. Nortautas Statkus and Kęstutis Paulauskas urged the country to reconsider Lithuania's policy of euroatlantism, which "should not be the dogma of the country's foreign policy"12, Česlovas Laurinavičius and others urged it to turn to "normal balancing within the limits of Lithuanian collective commitments" ${ }^{13}$, or, according to Raimundas Lopata, to perceive the paradigm

\footnotetext{
${ }^{8}$ See for more: Urbelis V., Lietuvos vieta JAV didžiojoje strategijoje, [Lithuania's Place in the US Large Strategy] Vilnius, 2005; also Jakštaitė G., Rusijos sulaikymo ir ịtraukimo strategijos šiuolaikinèje JAV užsienio politikoje ir Baltijos šaliu reikšmingumas [ Russia's Containment and Engagement Strategies in the Modern US Foreign Policy and the Significance of the Baltic States], VDU, 2012

${ }^{9}$ Larrabee F. S., Chivvis, Ch. S., "Biden's Task in Eastern Europe: Reassurance", RAND, 18122012

${ }^{10}$ Speech of Interim President Arturas Paulauskas at Vilnius University Naujoji Lietuvos užsienio politika [Lithuania's New Foreign Policy] http://paulauskas.president.lt/one.phtml?id=4994, 12092012

${ }^{11}$ Nekrašas E., "Kritiniai pamąstymai apie Lietuvos užsienio politiką [Critical Thougths on the Lithuanian Foreign Policy]", Politologija, 2 (54), 2009, p. 127;

${ }^{12}$ Statkus N., K. Paulauskas K., "Lietuvos užsienio politika tarptautinių santykių teorijų ir praktikos kryžkelèje [Lithuanian Foreign Policy at the Crossroads of International Relations Theory and Practice]", Politologija, 2 (42), 2006, p. 54

${ }^{13}$ Laurinavičius Č., Lopata R., Sirutavičius V., "Kritinis požiūris ị Lietuvos užsienio politiką: kas pasikeitė nuo Augustino Voldemaro laikų [Critical Attitude Towards the Lithuanian Foreign Policy: What has Changed since the Times of Augustinas Valdemaras] “, Politologija, 2 (54), 2009, p. 117
} 
of "both NATO and the EU" as "the permanent solution of two loyalties whose criterion was a real rather than formal withdrawal from the sphere of influence of the East"14. Attempts were made to counterpose the conception of golden province of Europe $\mathrm{e}^{15}$ with the conception of Lithuania as the leader of the region, to revive the ideas of good neighborhood ${ }^{16}$, but, on the whole, a clearer vision of Lithuania's foreign policy is absent. ${ }^{17}$

This article argues that transatlantic relations continue to be an inexhaustible theme of both the foreign and defense policy of Lithuania and of academic discussions. In the most general sense transatlantic relations mean the relation between the USA and Europe; the conception of the Transatlantic Security Community encompasses the following: a) the common identity and values, b) (economic) interdependence, c) common institutions based on the norms regulating these relationships ${ }^{18}$; in other words, it means a deeply integrated social group. The collective study Beieškant NATO Lietuvoje (In Search of NATO in Lithuania) ${ }^{19}$ devoted to the discussion of Lithuania's experience in NATO points out that even almost a decade after membership, the Alliance has not become a part of us yet; rather, it is perceived as "they", "others", etc. According to Shapiro and Witney, the anti-missile history revealed a profound lack of trust by new NATO and EU members in the solidarity of the communities and their collective strength ${ }^{20}$. Though the USA and Europe are the most important trading partners for each other, Russia remains Lithuania's main trading partner - it takes the first place according to both import and export volumes: in 2011 this accounted for 32.8 percent and 16.6 percent, respectively, of the total volumes, the largest part being energy resources ${ }^{21}$. Meanwhile

\footnotetext{
${ }^{14}$ Lopata R., Debatai dèl Lietuvos užsienio politikos [Debates about Lithuania‘s Foreign Policy], Politologija 1 (57), 2010, p. 130

${ }^{15}$ Aslo see: K. Girnius, Ar esame Europos provincija? [Ar we Europe‘s Province?] http://www.delfi.lt/ news/ringas/lit/kgirnius-ar-esame-europos-provincija.d?id=50335636, 12092012

${ }^{16}$ The Programme of the 15 th Government of the Republic of Lithuania, Valstybes žinios [Offical gazette], 2012-12-20, Nr. 149-7630

${ }^{17}$ Girnius K., Prezidentes užsienio politika - važiuoti ar nevažiuoti? [The President's Foreign Policy - to Go or not to Go?] http://www.delfi.lt/news/ringas/lit/kgirnius-prezidentes-uzsienio-politika-vaziuoti-arnevaziuoti.d?id=58735513, 13092012

${ }^{18}$ Risse T., "Beyond Iraq: The Crisis of the Transatlantic Security Community“, in: Ifantis K. et al, Multilateralism and security institutions in an era of globalization, London: Routledge, 2008, p. 78

${ }^{19}$ Jakniūnaitė D., Paulauskas K., ed. Beieškant NATO Lietuvoje [In Search for NATO in Lithuania], VU TSPMI, 2010

${ }^{20}$ Shapiro J., Witney N., Towards a Post-American Europe: A Power Audit of EU-US Relations, ECFR, http://pasos.org/wp-content/archive/ECFR_EUUSrelations.pdf, 29122012

${ }^{21}$ Information of the Foreign Ministry of the Republic of Lithuania, https://www.urm.lt/index.

php?4025573062, 26012013
} 
the USA is neither among the ten main trading partners nor investors ${ }^{22}$. Together with its partners Lithuania has assured NATO defense plans for the Baltic States, however, the expenses it allocates to the defense budget (like those of the majority of other European states) decreased to the critical limit - in 2012 they accounted for as little as 0.8 percent of GDP. On the whole, Europe, being dependent on US military power, paradoxically lacks a common European attitude to the USA and transatlantic relations, as well as other growing powers. President Obama's first term of office was noted not only for "resetting" relations with Russia but also for shifting the US attention to other regions, first and foremost, to the Asian-Pacific region ${ }^{23}$, thus the analysts on both sides of the Atlantic speculate about how the USA and Europe could remain "irreplaceable partners" to each other in the future ${ }^{24}$. Lithuania, being a full member of the Euroatlantic Community ${ }^{25}$, should take part in this discussion.

All the more so with Lithuania's NATO membership, which strengthened the region's security considerably when the probability of the existential threat was assessed as non-existent or at least as minimal, the matter has not been completely resolved, because:

- Lithuania, being a small country, due to its geopolitical position, has to constantly watch and assess changes in the external environment and react to them adequately;

- Lithuania's membership of the North Atlantic Alliance does not release it from the necessity to develop its defense capacities (and allocate adequate financing to it);

- Taking into consideration economic-social aspects of security, deeper integration into the transatlantic security community should be sought in this sphere too to strengthen relevant institutions and values.

Seeking to give an answer to these questions, the following theoretical suppositions will be taken as the basis: according to the neoclassical realist

\footnotetext{
${ }^{22}$ United States Census Bureau, U.S. International Trade in Goods and Services - Annual Revision for 2011, http://www.census.gov/foreign-trade/Press-Release/2011pr/final_revisions/11final.pdf, 1109 2012; Department of Statistics of the Republic of Lithuania, Tiesioginès užsienio investicijos metu pabaigoje [Foreign Direct Investments at the End of the Year], 18092012

${ }^{23}$ Manyin M., E., Daggett S., Dolven B., Lawrence S.V., Martin M. F., O`Rourke R., Vaughn B., Pivot to the Pacific? The Obama Administration 's "Rebalancing “ Towards Asia, Congressional Research Service, March 28, 2012, http://www.fas.org/sgp/crs/natsec/R42448.pdf, 29122012

${ }^{24}$ See for more: Lagadec E., Transatlantic Relations in the 21st Century: Europe, America and the Rise of the Rest, Routledge, 2012

${ }^{25}$ Resolution of the Seimas of the Republic of Lithuania concerning Trends in the Foreign Policy, 1 May 2004.
} 
theory, the foreign policy of a small country is determined to a large extent by the structural factors of the international system, and the geopolitical position of the state; however the pressure of the external environment affects it through intervening unit-level factors, such as a state structure and decisionmakers' perceptions.

\section{A Small Country in the International System: in Search of Security}

\subsection{Security}

In international security studies, security is usually discussed within the context of power policy and is related to the traditional political-military conception of security in which security in essence means the survival or absence of a threat. According to Glen Snyder, security means "strong confidence that the values held onto (i.e. territorial integrity, political independence, etc.) will be protected in case of an external military threat" ${ }^{26}$. From Ken Booth's viewpoint, security means survival-plus ${ }^{27}$, i.e. not only absence of a threat to the survival but also certain choices of life. The dilemma of security on the whole is considered to be a fundamental conception in security studies because, according to Booth and Wheeler, it is related to the existential condition of uncertainty characteristic of all kinds of relations between the people, not only to interaction on the most aggressive - international arena ${ }^{28}$. It is thought that one government or policy maker cannot be absolutely sure of other actors who can have an impact the state's security, of present and future intentions and motives ("unsolvable uncertainty"), therefore, when assessing possible threats, one has to be very conservative.

The security issue usually arises when existential threat to a certain object (traditionally but not necessarily, to a state, a nation) is posed by other actors of the international system (e.g., by revisionist states), which have more power (military, economic) and which are in a geographical proximity and have hostile intentions. According to Statkus and Paulauskas, on the basis of the neo-realistic paradigm, the state's safe existence is assured when other sta-

\footnotetext{
${ }^{26}$ Snyder G., Alliance Politics, 1997, Cornell University Press, p. 5

${ }^{27}$ Booth K., Theory of World Security, Cambridge University Press, 2007, p. 95

${ }^{28}$ Booth K., Wheeler, N. J. "Uncertainty”, in: Security Studies: An Introduction, ed. P. Williams, 2008, p. 133
} 
tes either have no hostile intents or power to realize them ${ }^{29}$. The strategy of the states in the presence of threats is usually aimed at seeking to balance and thus maintain status quo, or seeking for more power.

There exists another viewpoint, which maintains that security arises from the cooperation relation rather than from the ability to concentrate and use power against others. The so-called Copenhagen School questions the conception of objective security (with the exception of the obvious cases of a direct threat) and states that in many cases it is socially constructed and intersubjective ${ }^{30}$. Statements can be found in literature that security is self-referential practice, or it is the way a certain issue becomes a security issue: it does not necessarily have to pose a real existential threat and is presented by a speaker as such and understood by the audience as a threat to the survival (identity). In other words, security does not belong either to the object or subject, it exists among the subjects ${ }^{31}$. According to Buzan and others, "securitization" of the issue moves policy beyond the limits of the established rules of the game making it the object of the "extraordinary" policy (or: the above-policy object) ${ }^{32}$, which makes the use of any means (e.g. the use of force, universal mobilization) essentially justified.

The criteria according to which a certain issue is recognized as having existential significance are as follows: when it is possible to argue that it is more important than all others and it should be given absolute priority; that without solving this issue all others can become unimportant; the issue does not fit in the framework of usual politics. Security issues, however, must not be made absolute in a democratic state (e.g., due to the danger to use them for the purpose of the internal policy); in the ideal case policy must be able to evolve on the basis of routine procedures without resorting to immediate extreme measures. The optimal long-term strategy is the desecuritization strategy, which seeks the solution of certain issues out of the discourse area of "a threat-countermeasure" and moves towards the ordinary public sphere ${ }^{33}$. Maria Mälksoo has called the foreign policy of the Baltic States existential, which, following the states' integration in NATO and EU, gradually had to turn into

\footnotetext{
${ }^{29}$ Statkus N., Paulauskas K., Tarp geopolitikos ir postmoderno: kur link sukti Lietuvos užsienio politikai ?[In Between Geopolitics and Postmodernism: What Direction the Lithuanian Foreign Policy Take?], Vilnius, 2008, p. 22-23

${ }^{30}$ See for more: Wæver, O. "Securitization and Desecuritization" in: Lipschutz R., ed., On Security, New York: Columbia University Press, 1995, p. 46-86.

${ }^{31}$ Buzan B., Weaver O., de Wilde J., Security: A New Framework for Analysis, 1998, p. 31

${ }^{32}$ Ibid., p. 23

${ }^{33}$ Ibid., p. 29
} 
normal politics ${ }^{34}$. Transnational integration and creating a collective identity is the solution of the security problem proposed by the constructivists; however, contemporary security theoreticians tend to underline the synthesis of both viewpoints in seeking for the solution of security problems.

\subsection{The Small State}

The small states, to which Lithuania is attributed, are regarded as especially sensitive in the security issues because they have "limited power and have no possibilities to exert essential influence on the actual world order" 35 . The small states have not been studied extensively enough in academic literature; they were even considered ignored ${ }^{36}$, because on the basis of the (neo) realistic paradigm (Waltz, Carr, Morgenthau, Niebhur and others), the behavior of the small states in the international system is restricted to a great extent (and explained sufficiently well) by the structural factors, contrary to the case of the large states. The small states are usually treated as the object rather than the subject of international relations.

A state is usually attributed to one of the following categories - super power, large, medium, small power or a mini state - on the basis of the objective material parameters of its power. According to Robert Rothstein ${ }^{37}$, the following features are characteristic of the small state: 1) it admits that it cannot ensure security with its own means available therefore it has in essence to rely on help provided by other states, institutions, processes or development of events, 2) the narrow margin of safety is characteristic of it, 3) the leaders of the state understand its weakness as an attribute that in essence cannot be changed. The foreign policy of the states that do not influence the international system (i.e. the small states) is treated as "adaptation to the reality" rather than restructuring it in the classification presented by Robert O. Keohane ${ }^{38}$. Other features characteristic of the foreign policy of small states: narrow range of foreign policy issues (often

\footnotetext{
${ }^{34}$ Mälksoo M., "From Existential Politics Towards Normal Politics? The Baltic States in the Enlarged Europe", Security Dialogue, September 2006, vol. 37, no 3., pp. 288, http://sdi.sagepub.com, 24022007 ${ }^{35}$ Jankauskas A., ed., Politikos mokslų enciklopedinis žodynas [Encyclopedic Dictionary of Political Science], VU TSPMI, 2007, p. 77

${ }^{36}$ See for more: Handel M., Weak States in the International System, 1990, Frank Cass \& Co Ltd, ; Elman M., "The Foreign Policies of Small States: Challenging Neorealism in Its Own Backyard", British Journal of Political Science, Vol. 25, No. 2 (Apr. 1995), pp. 171-217, http://www.jstor.org/stable/194084, 29122012

${ }^{37}$ Rothstein, R., Alliances and Small Powers, Columbia University Press, 1968

${ }^{38}$ Keohane R.O., "Lilliputians‘ Dilemmas: Small States in International Politics", in: International Organization, Vol. 23, No. 2, Spring 1969, pp. 291-310
} 
limited to nearby regions); focus on international law and institutions; underlining moral principles; relying on a super power in issues of security; flexibility and creativeness. Many authors underline the geographical (in other places - geopolitical) factor as the primary one, which influences the foreign policy of the small states - that is, the military and strategic situation of the state (neighborhood of more powerful states, intersecting interests are regarded as an unfavorable position), its natural resources, dependence on their import and others, as well as a characteristic consensus on the issues of the foreign policy.

Michael Handel uses the definition of a weak state ${ }^{39}$, where not only objective but also certain "intuitive" criteria, such as absence of strength rather than the size of the country, are of importance; it is underlined that the state's strength or weakness is sooner a relative than absolute magnitude, a dynamic rather than fixed feature. He distinguishes the internal sources, such as geographical conditions, human resources, organizational abilities (political institutions, etc.) and external sources of the state's strength, that is, formal and informal alliances. Alliances of a different nature are considered a primary instrument of national security policy, a characteristic strategy of the behavior of a small state in international politics. Though the primary purpose of the alliance is a joint rebuff of the external threats, its additional internal ties, such as mutual trade or common values are of no less significance. In his study on alliance formation ${ }^{40}$, Stephen M. Walt makes a conclusion that common interests strengthen the ties of the alliance more than a common ideology. With a threat increasing (for instance, with a change in the balance of powers in the international system), rational behavior of the state is, according to Snyder, to strengthen the ties of the alliance, to support the allies, to create a reputation of a loyal, determined partner, to underline mutual dependence and commitments. According to Handel, weak states can never afford to lose vigilance in the security matters or merely enjoy the security provided by the super power.

It has been noted that the small states often are not helpless victims of the system; on the contrary, they are able to make an efficient use of the possibilities of the international system, and to manipulate the power of the large states for their own benefit. The state's "soft power" 41 , that is, communicative, organizational, institutional abilities, making use of interdependence, and especially the ability to accurately react to new information, are mentioned as significant factors

\footnotetext{
${ }^{39}$ See for more, Handel M., Weak States in the International System, 1990, Frank Cass \& Co Ltd, p. 68

${ }^{40}$ Stephen M. Walt, ,Alliance Formation and the Balance of World Power“" International Security, Vol. 9 , No. 4, Spring 1985 , p. 3-43

${ }^{41}$ See for more, Nye J. S., "Soft Power", Foreign Policy, No. 80, Autumn 1990, http://faculty.maxwell. syr.edu/rdenever/PPA-730-27/Nye\%201990.pdf, 16022013
} 
when speaking about economic, social security, as well as about powers of the states within the context of the European Union (e.g., putting forward innovative ideas, the ability to form the agenda or a discourse by changing preferences of other actors). One of the examples of how a small state can influence the international system is the Scandinavian countries, which have become established in the world community as creators of certain norms in international politics.

Theorists of neoclassical realism (Rose, Schweller, Lobell and others) emphasize that unit-level variables, such as a state structure, its decision-makers' perceptions, key social and economic actors, and a lack of consensus among them can prevent states from adapting rationally to changes in the international environment (i.e., shifts in power). Identification and assessment of threats and strategic adjustment is a complex rather than a single-minded process, entailing considerable bargaining within the state's leadership and other important stakeholders. Lobell points out ${ }^{42}$ that the foreign policy executive, standing at the intersection of international and domestic politics, should forge and maintain a coalition with various societal elites. According to Randal Schweller, historical experience shows that the states often assess and balance their behaviur in the presence of arising threats insufficiently ${ }^{43}$.

In summary, the following relevant factors can be distinguished within the context of the problem in question:

- The international system sets certain opportunities and constraints for the foreign policies of the states; the small states are especially sensitive in their security issues;

- A change in the balance of powers in the international system is assessed as an increasing threat to security, at the same time taking into consideration the geographical (geopolitical) factor too;

- The rational behavior of the state is to balance or acquire more power (external or internal strength); strengthening the ties of the alliance and interdependence;

- It is within the state (institutions/political elite) that decisions on the origin and nature of arising threats to security and the necessary measures to be taken are made; a lack of consensus between the foreign policy executive and key societal actors can impede the process of foreign policy adjustment.

\footnotetext{
${ }^{42}$ Stephen E. Lobell, "Threat assessment, the state, and foreign policy: a neoclassical realist model", in: Neoclassical Realism, the State and Foreign Policy, Lobell S., Ripsman N., Talliaferro J.W., eds., 2009, p. $42-74$

${ }^{43}$ Schweller R. L., Unanswered Threats. Political Constraints on the Balance of Power, 2006, p. 10-11
} 
The global security environment is constantly changing, it is dynamic, and the agendas of politics change respectively. After the elections of the President and the Congress that took place in 2012, the assessment of possible changes in the US foreign policy became one of the most important issues for Lithuanian policy makers.

\section{Growing "Others" and the Global US Agenda}

\subsection{Changing Balance of Powers}

The feeling that it is losing its role as hegemon in the world, which the USA became after the Cold War, has prevailed for some time already, ${ }^{44}$ though the USA is still the strongest global power and likely will remain so in the future. According to Fareed Zakaria, during the recent years the USA has not become weaker but, rather, "all the others are growing" 45 . The "9/11 shock" has become one of the factors that destroyed America's self-confidence and changed its understanding of threats, states Zbigniew Brzezinski ${ }^{46}$. In his opinion, the world "after America", that is, with its power gradually declining, seems much less safe ${ }^{47}$. According to the data of the statement The Global Trends 2025 of the National Intelligence Council ${ }^{48}$, the probable scenario of the future of the world is the formation of a global multi-polar system due to the growing new powers (China, Russia, India and others), the shift of economic power referred to as the historical one from the West to the East and the increasing influence of the non-state actors. It is forecasted that new players will bring new rules of the game into the system, and a threat arises that the traditional Western alliances would be weakened. The analysts, when speaking about the tendencies of recent years, alongside globalization mention strengthening of regionalism and, besides the Asian region, indicate the regions of Latin America, the Middle East and Africa as demanding USA's attention. The major threats identified are global ones, such as expansion of nuclear weapons of mass

\footnotetext{
${ }^{44}$ See for example, Layne, Ch., "The Waning of US Hegemony - Myth or Reality? A Review Essay", International Security, vol. 34, no. 1, Summer 2009, pp. 147-172

${ }^{45}$ See for more: Zakaria F., The Post-American World, W.W. Norton \& Company, 2008

${ }^{46}$ Bzrezinski Z., Scowcroft B., America and the World: Conversations on the Future of American Foreign Policy, Basic Books, 2008, p. 3

${ }^{47}$ Brzezinski Z., "After America“, http://www.foreignpolicy.com/articles/2012/01/03/after_america, 2501 2013

${ }^{48}$ National Intelligence Council, The Global Trends 2025:A Transformed World, November 2008, http:// www.dni.gov/nic/NIC_2025_project.html, 25012013
} 
destruction, terrorism, issues of economy and energy, climate warming, etc. The majority of them, such as the issues of cyber security, are reflected in the NATO New Strategic Concept ${ }^{49}$.

The changing view of the world due to globalization and the increased threats is also stated in the US National Security Strategy approved in $2010^{50}$. The Strategy states that the USA fought against "a wide network of violence" for almost a decade therefore the time has come for the USA to renew itself - to strengthen its economy and to reduce the budget deficit, to invest in education, energy, innovations, and competitiveness in the world market - and to assess its global role anew. The document characterizes NATO as "the exceptional Alliance of security" in the world and the relations with the allies in Europe (the United Kingdom, France, Germany, in particular) are identified as the "corner stone" of USA's involvement in the world. The commitment to Article 5 of the Washington Treaty is emphasized once again; however, at the same time, it is underlined that the Alliance has to be reformed on the basis of the NATO New Strategic Concept. The commitment to partnership with the stronger European Union is expressed by seeking common goals, including encouraging democracy and welfare in the countries of Eastern Europe, which are still transitioning to democracy. However, in fighting against the global challenges it is planned to create new partnerships and develop cooperation with the rising "key centers of influence" - China, India, Russia, as well as Brazil, South Africa, Indonesia and other growing powers. The strategic "pivot" of America towards the Asian-Pacific region is one of the essential features of Obama's first term of office, which, by assessment of some analysts, will continue in the future due to "economic and geopolitical charm of China"51, though the latest opinion polls show again the significance of transatlantic relations ${ }^{52}$.

After the elections of the US Congress and the President in 2012, which ended in Obama's victory, analysts tried to forecast the future foreign policy of the country and to identify the main objectives of the foreign policy that the President is expected to achieve during his second term of office. Certain changes in politics are likely for the simple reason that some important members in Obama's Cabinet have changed-the new Secretary of the State

\footnotetext{
${ }^{49}$ NATO, The 2010 Strategic Concept, http://www.nato.int/cps/en/natolive/official_texts_68580.htm, 03 122012

${ }^{50}$ National Security Strategy, http://www.whitehouse.gov/sites/default/files/rss_viewer/national_security_strategy.pdf, 03122012

${ }^{51}$ For example, Engel R., „Top 10 Foreign Policy Issues Facing Obama”, NBC News, 7 November 2012

${ }^{52}$ The German Marshall Fund of the United States, Transatlantic Trends 2012, http://trends.gmfus.org/ transatlantic-trends-2012-released/, 30122012
} 
Kerry, Defense Secretary Hagel and others have been appointed. However, the majority of commentators identified the key objectives of the foreign policy as similar to those during the President's first term of office: the withdrawal of the US forces from Afghanistan, Iran, Israel and Syria ${ }^{53}$, as well as North Korea. The latter issues are expected to dominate the transatlantic agenda alongside the issues of terrorism, trade and relations with Russia. The President's new term of office gives him the opportunity to look anew at the relations with the "key foreign partners", including the new President of Russia Vladimir Putin.

\subsection{The End of "Reset"?}

The global agenda and understanding of global threats have an effect on constructing USA's relations with Russia: to begin the "reset" seeking for cooperation on the basis of mutual interests - reduction of the arsenal of nuclear weapons in both countries; a fight against terrorism (especially in Afghanis$\tan$ ); cooperation in the sphere of trade. The National Security Strategy also specified the aspiration to create a "stable substantive, multidimensional relation" with the player that has reappeared in the international system seeking to achieve mutually beneficial objectives.

As previously mentioned, the policy of the "reset" of the relations that caused a certain concern to the CEE governments is assessed in the USA itself in an ambiguous way. According to the assessment of the US Council on Foreign Relations the "reset" helped improve the relations between the USA and Russia; however, disagreements between the countries still existed on many issues, especially concerning the creation of the US anti-missile defense shield in Europe, and recently a deterioration in the relations has been observed. In the opinion of Steven Pifer, the "reset" stage with relatively easy issues of the bilateral agenda has passed already, the elections in both states have come to an end, thus the question whether Russia was ready to re-engage and cooperate in the issue of reducing the nuclear arsenal or the compromise concerning antimissile defense shield in Europe remained open.

There are people who think that the main problem is the drifting of the USA itself, having concentrated on a fight against terrorism and without having developed a global vision during the past decade, whereas its rivals,

\footnotetext{
${ }^{53}$ Robinson, D. "Obama Has Opportunities, Challenges in Second Term", Voice of America, January, 17, 2013, http://www.voanews.com/content/obama-has-opportunities-challenges-in-second-term/1586094. html, 18012013
} 
including Vladimir Putin, do not conceal their ambitions ${ }^{54}$. The latter seeks for strengthening of the regime, re-industrialization of the country and "excessively concentrates" on the security matters. One of the examples is the militarization of Kaliningrad Region of the Russian Federation ${ }^{55}$. Russia's military doctrine of 2010 identifies the use of NATO capacities for defensive purposes and the development of infrastructure in the Member States in the vicinity of the borders of the Russian Federation as one of major military threats ${ }^{56}$. Russia's growing power is related to its energy resources. US Secretary of State Clinton, at the end of her term of office, stated that Russia sought to expand its political and economic influence on the former countries of the USSR: to "re-sovietize" the region under the cover of regional integration. Meanwhile Moscow, according to the Vice Prime Minister Dmitrij Rogozin, does not believe the statements made by Washington that anti-missile defensive shield in Europe was not directed against Russia ${ }^{57}$. Therefore, though Russia is no longer the existential threat that the Soviet Union posed, regulation of relations with it, in the opinion of experts, remains the essential strategic task for both the United States and Europe ${ }^{58}$, since Russia is thought to be able to pose a direct challenge to the present international (in Russia's understanding - dominated by the USA) system ${ }^{59}$.

These trends and circumstances should draw the attention of the foreign policy-makers of the states of the Baltic region, which, according to Edward Lucas, is the most vulnerable European region.

\footnotetext{
${ }^{54}$ See for more Engel R., “Top 10 Foreign Policy Issues Facing Obama”, NBC News, 7 November 2012; Opinion, The Huffington Post, 13 November, 2012

${ }^{55}$ Resolution of the European Parliament on the Annual Report of the Council to the European Parliament concerning the Common Foreign and Security Policy (12562/2011 - 2012/2050(INI)), 20120912

56_See for more: RF Military Doctrine, http://www.scrf.gov.ru/documents/18/33.html, 16022013

${ }^{57}$ „We Don’t Take Americans on Trust- Rogozin on AMD“, http://rt.com/politics/rogozin-missile-defenseobama-221/, 18012013

58 Michel, L., "Baltic Security: Why the United States (still) Cares", in: Nurick R., Nordenman M., eds., Nordic-Baltic Security in the $21^{\text {st }}$ Century: The Regional Agenda and the Global Role, Atlantic Council September 2011, p. 23 http://www.acus.org/files/publication_pdfs/403/090711_ACUS_NordicBaltic.PDF, 30122012

${ }^{59}$ The Global Trends 2025, p. 94; t.p. „Navigating Uncertainty. U.S. - Central European Relations 2012“, Centre for European Policy Analysis, July 2012, p. 91, http://cepa.org/publications/home.aspx, 25012013
} 


\section{Threats to the Alliance and the Decreasing Power of Europe}

The report The Global Trends 2025 specifies that recently NATO has been encountering serious challenges related to the ability of undertaking an ever increasing responsibility that extends beyond the borders of the Alliance and the decreasing military capacities of Europe. Weakening of traditional alliances is forecasted in the future, and at the same time it is almost unanimously agreed as to the spread of increased insecurity in the 21st century.

As Jovita Pranevičiutee has observed, after September 11, 2001, attacks in the USA, the list of the North Atlantic Alliance threats started to expand and each review of the NATO strategy added "one more or several definitions of the new threats, challenges or risks" ${ }^{\circ}$. Different NATO members, however, see the threats posed to the Alliance in a different way - from traditional to the new threats of terrorism, development of weapons of mass destruction, energy and others. On the basis of all that and the imagined role of NATO in the future, the countries of the Alliance are divided into three groups: "reformers", "supporters of status quo" and "propagators of a return to themselves". Poland, the Czech Republic and the Baltic States, which accentuate the real implementation of Article 5 and which speak for planning conventional armament, the nuclear deterrence strategy and, according to Pranevičiūte, the only potential threat which has not been openly identified by anybody is Russia.

The paradox, however, is that with the list of potential threats growing, expenses of the majority of allies on defence have decreased. During the economic financial crisis the majority of governments were made (or at least considered) to resort to strict saving measures, including a reduction of expenses on national defence. Meanwhile recent NATO operations in Afghanistan and Libya revealed certain weaknesses of the allies - only a small part of the Alliance members were able to undertake the "hard" (i.e. fighting) part of the task. The so-called "burden sharing" problem came to light once again, and NATO and US officials started to speak ever louder about the necessity for the Europeans to invest in their defense.

Twenty-eight members of the Alliance are taking part in its activities in several ways; however, participation in NATO operations, as well as possibilities to deploy their armed forces is considered to be the main way. For exam-

\footnotetext{
${ }^{60}$ Pranevičiūtè, J., Kas ko bijo Šiaurès Atlanto aljanse: naujos ir senos grèsmès [Who is Afraid of Who in the Atlantic Alliance: New and Old threats], http://www.delfi.lt/news/ringas/abroad/jpraneviciute-kas-kobijo-siaures-atlanto-aljanse-naujos-ir-senos-gresmes.d?id=38298463, 18012013
} 
ple, the Afghanistan International Security Assistance Force (ISAF) operation (a total of 49 countries participate in it - the greatest part of them are EU states, including Lithuania) ${ }^{61}$ to be continued until 2014.

The key discussions about division of expenses in the Alliance are held with respect to deployment of the armed forces in NATO operations since this constitutes the largest part expenses related to NATO membership. At the present time only five NATO countries allocate the agreed 2 percent of GDP to the defense of the country, and the expenses allocated of the European countries have decreased by almost 15 percent during the past decade. Besides, when assessing the indicators of the defense budget of the countries, not only the absolute figures are taken into consideration but also proportions allocated to the staff, renewal of the armament and other things. During the recent years the average of NATO countries (with the exception of the USA) allocated to acquisition of equipment accounted to as little as 16.7 percent (in some Member States - less than 10 percent); this raises doubts about the capabilities of the allies to repel traditional and new threats, and to participate in new operations. According to the amount of expenses allocated to its defense, Lithuania is nearly in last place (see Table 1). By the assessment of the international expert group, if the present tendencies remain Lithuania might be unable to carry out its Alliance membership commitments in the future ${ }^{62}$.

Table 1. Expenses of NATO countries on defense ${ }^{63}$

\begin{tabular}{|l|c|c|c|}
\hline Country & $\begin{array}{c}\text { Expenses on defense } \\
\text { in 2005-2009 } \\
\text { (average, per cent } \\
\text { from GDP) }\end{array}$ & $\begin{array}{c}\text { Expenses on defen- } \\
\text { se in 2009 } \\
\text { (per cent from GDP) }\end{array}$ & $\begin{array}{c}\text { Expenses } \\
\text { on defense* } \\
\text { in 2011 } \\
\text { (per cent from GDP) }\end{array}$ \\
\hline USA & 4.5 & 5.4 & 4.8 \\
\hline Turkey & 3.2 & 2.1 & 1.9 \\
\hline Greece & 2.9 & 3.2 & 2.1 \\
\hline United Kingdom & 2.3 & 2.7 & 2.6 \\
\hline France & 2.3 & 2.1 & 1.9 \\
\hline
\end{tabular}

\footnotetext{
${ }^{61}$ NATO, International Security Assistance Force (ISAF): Key Facts and Figures, http://www.nato.int/ isaf/docu/epub/pdf/placemat.pdf, 13092012

${ }^{62}$ Kaljurand R., Neretnieks K., Ljung B., Tupay J., "Developments in the Security Environment of the Baltic Sea Region up to 2020", September 2012, http:/www.icds.ee/fileadmin/failid/Developments $\% 20$ in $\% 20$ the $\% 20$ Security $\% 20$ Environment $\% 20$ of $\% 20$ the $\% 20$ Baltic\%20Sea $\% 20$ Region $\% 20$ up $\% 20$ to $\% 20$ 2020.pdf, 05012013.

${ }^{63}$ Compiled by the authors on the basis of 2012 NATO reports about Expenses of the Member States on Defence, Financial and Economic Data Relating to NATO Defence, April 13, 2012, http://www.nato.int/ nato_static/assets/pdf/pdf_2012_04/20120413_PR_CP_2012_047_rev1.pdf, 14092012
} 


\begin{tabular}{|l|c|c|c|}
\hline Bulgaria & 2.2 & 1.9 & 1.4 \\
\hline Norway & 1.9 & 1.7 & 1.5 \\
\hline Poland & 1.7 & 1.7 & 1.7 \\
\hline Estonia & 1.6 & 1.8 & 1.7 \\
\hline Slovakia & 1.6 & 1.5 & 1.1 \\
\hline Italy & 1.6 & 1.4 & 1.4 \\
\hline Portugal & 1.5 & 1.6 & 1.5 \\
\hline Slovenia & 1.5 & 1.6 & 1.3 \\
\hline Czech Republic & 1.5 & 1.6 & 1.1 \\
\hline Croatia & no data & 1.6 & 1.5 \\
\hline Albania & no data & 1.5 & 1.5 \\
\hline Netherlands & 1.5 & 1.5 & 1.3 \\
\hline Denmark & 1.4 & 1.4 & 1.4 \\
\hline Romania & no data & 1.4 & 1.3 \\
\hline Latvia & 1.4 & 1.2 & 1.0 \\
\hline Canada & 1.3 & 1.4 & 1.4 \\
\hline Germany & 1.3 & 1.4 & 1.4 \\
\hline Hungary & 1.3 & 1.2 & 1.0 \\
\hline Spain & 1.2 & 1.2 & 0.9 \\
\hline Belgium & 1.1 & 1.2 & 1.1 \\
\hline Lithuania & 1.1 & 0.4 & 0.5 \\
\hline Luxemburg & 0.5 & & \\
\hline
\end{tabular}

By its official documents Lithuania has confirmed more than once its commitment to adequately financing national defense. This has been done through agreements of political parties of 2001, 2004, Resolution of the Seimas of the Republic of Lithuania of 1 May 2004, in which it was promised to allocate at least 2 percent of GDP as far back as 2005-2008, and finally the latest agreement of May 2012. However, thus far there has been no agreement about how this will be implemented. The National Security Strategy treats insufficient financing of the defense sphere as one of the factors of internal risk, which can have a great effect on national security of the Republic of Lithuania.

In his farewell speech made on 10 June 2011, the US Defense Secretary Robert Gates unambiguously warned the allies in Europe about "a dim, if not dismal future for the transatlantic alliance" if the NATO member states do not seriously undertake expenses on defense and will participate in NATO operation more fully and actively. After the Cold War the share of the USA in the NATO defense budget increased from 50 percent to more than 70 percent, 
whereas expenses on defense of economically strong European countries were constantly on the decrease (See Fig. 2), some part of them are "specializing" in the "soft" tasks.


Figure 1. General Defense Expenditures of NATO Members

According to Gates, Europe cannot expect the US tax payers to pay for its security forever: if downtrends of defensive capacities of Europe remain unchanged, the future generation of the US political leaders, which grew up after Cold War, might "see no sense in America's investments in NATO"64.

US warnings to Europe are related to the intentions of America itself to limit its military expenses within the context of acute political debates about a general reduction of the budget deficit of the country. In 2011, the US expenses on defense amounted to almost 700 billion US dollars - the defense budget itself totaled 530 billion US dollars, while 160 billion US dollars was allocated additionally for the needs of the wars in Afghanistan and Iraq. The Act on Budget Control that came into effect in 2011 provided for reducing the US budget deficit by 1.5 trillion US dollars in 2013-2021, including a reduction of expenses of the military budget. During the time of preparing this clause it was not known yet on what further measures for reducing the budget the leaders of the Democrats and Republicans were going to agree, but the current debt of the federal budget amounting to 16 trillion US dollars (exceeding GDP of the USA) is assessed by the representatives of the American political elite as a "national security crisis" in the sense of economic security ${ }^{65}$. The size of the current debt is such that, according to Peter W. Singer, it would be enough to purchase 16 Marshall plans or 16 NATO military budgets. True, America's power even in the worst-case scenario, the case of sequestration, is going to remain sufficiently large: the planned US

\footnotetext{
${ }^{64}$ Gardiner N., "America's European allies must heed US Defence Secretary Robert Gates' warning on the future of NATO", The Telegraph, June 10, 2011,

http://blogs.telegraph.co.uk/news/nilegardiner/100091737/america\%E2\%80\%99s-european-allies-mustheed-us-defence-secretary-robert-gates\%E2\%80\%99-warning-on-the-future-of-nato/, 30122012 ${ }^{65}$ Singer P. W., "Separating Sequestration Facts from Fiction: Sequestration and What It Would Do for American Military Power", Time Magazine, http://www.brookings.edu/research/articles/2012/09/23sequestration-defense-singer, 30122012
} 
military budget will account for 38-40 percent of the total world military budget in 2013, whereas the indicators of the nearest potential rivals are much lower: China -8.2 percent, Russia -3.9 percent.

The defense strategy guidelines of the US Department of Defense issued in 2012 specify that the priorities of the US foreign and security policy are reoriented from Europe towards Asian-Pacific region and the Middle East ${ }^{66}$. This also means a strategically different redeployment of the US armed forces in the world, and the military bases and infrastructure related to them. For example, it is planned to reduce the number of soldiers stationed in Europe down to 70 thousand soldiers by 2015 (compare to the Cold War period - about 300 thousand US soldiers) ${ }^{67}$. Thus, both a further reduction of US defense expenses during the period between 2013 and 2021 and transfer of the arsenal of the identified main threats to other continents means only one thing: namely, that the allies in Europe must assume more responsibility for their own security, develop their defense capacities on the basis of the New NATO Strategic Concept, and bridge the gap separating them from the USA seeking a common objective - "NATO forces 2020". All countries are urged to contribute more to "smart defense" and the NATO Summit held in Chicago in 2012 identified the NATO Air Policing Mission in the Baltic States as one of the most successful examples of it.

\section{Challenges to Europe: Together or Separately?}

Hence, the following challenge is going to be posed to Europe: to assess the changed geopolitical picture of the world, as well as to assess the way Europe sees itself in that picture. It seems that during recent years the issues of Euro zone, the economic crisis, as well as problems of the Mediterranean Sea Region, has been given much attention in the European Union. In the opinion of José Manuel Barroso, President of the European Commission, in the presence of global challenges deeper economic and financial integration is necessary, that is, a federation of nation-states ${ }^{68}$, which, at minimum, the United Kingdom opposes.

\footnotetext{
${ }^{66}$ US Department of Defence, Sustaining US Global Leadership: Priorities for 21 st Century Defence, January 2012, http://www.defense.gov/news/Defense_Strategic_Guidance.pdf, 14092012

${ }^{67}$ Vandiver J., "Pentagon lays out significant cuts to U.S. Forces in Europe", Stars and Stripes, February 12, 2012, http://www.stripes.com/news/pentagon-lays-out-significant-cuts-to-u-s-forces-in-europe-1.168861, 18092012

${ }^{68}$ Barroso J. M., State of the Union 2012, http://ec.europa.eu/commission_2010-2014/president/pdf/brochure_en.pdf, 01032013
} 
The office of EU High Representative for the Common Foreign and Security Policy established after the Lisbon Treaty is one of the instruments in seeking for more coordinated and consistent foreign policy of the European Union $^{69}$. Europe, which accentuated economic integration for the past half century, seeks to define itself ever more clearly as a global political figure with a clearer external identity. Europe declares that the USA was its main strategic partner ${ }^{70}$ with which it wanted to cooperate in different spheres - from developing peace, stability and democracy in the world to a fight against global challenges but thus far more obvious progress has been achieved in developing economic relations. The volumes of EU and USA trade and investments are the largest in the world - about 31 percent of the total trade volumes and 49 percent of the total world GDP ${ }^{71}$. The perspective of the Transatlantic Trade and Investment Partnership, being considered on both sides of the Atlantic against the background of current economic challenges is expected to provide a stimulus and give mutual benefit when seeking for economic recovery. This is important to Lithuania in solving the issues of economic-social security: though from the point of view of EU membership there is a tendency towards accentuating the aspects of welfare, in 2011 as much as 33 percent of the inhabitants of Lithuania found themselves on the brink of poverty or social exclusion $^{72}$. Public opinion polls show a growing disappointment in democracy and market economy ${ }^{73}$.

So far transatlantic cooperation in the security sphere has been directed more towards crisis management ${ }^{74}$; however, it seems likely that time has come to develop not only "soft" but also "hard" security. At the end of 2012, the European Council commissioned the High Representative to prepare and submit the plan of measures of strengthening the Common Security and Defense

\footnotetext{
${ }^{69}$ See for more: Šešelgytė M., Lelevičiūtė I. „Lisabonos sutarties poveikis ES bendrai saugumo ir gynybos politikai" [Impact of the Lisbon Treaty on EU Common Security and Defence Policy], Lietuvos metine strateginé apžvalga, 2010-2011, t. 9, p. 95-125

${ }^{70}$ Scammell R., "Is Obama's Re-election Good for Europe”, http://www.eui.eu/News/2012/11-07-IsObamasre-electiongoodforEurope.aspx, 18012013

${ }^{71}$ EU External Action Service, United States of America, http://eeas.europa.eu/us/index_en.htm, 1801 2013

72 Eurostat newsrealease, 3 December 2012, http://epp.eurostat.ec.europa.eu/cache/ITY_PUBLIC/303122012-AP/EN/3-03122012-AP-EN.PDF, 10032013

${ }^{73}$ Confidence in Democracy and Capitalism Wanes in Former Soviet Union, December 5, 2011, http:// www.pewglobal.org/2011/12/05/confidence-in-democracy-and-capitalism-wanes-in-former-soviet-union/, 29122012

${ }^{74}$ EU-NATO Declaration on ESDP, http://www.consilium.europa.eu/uedocs/cmsUpload/73803\%20 -\%20Solana\%20-\%20Permanent\%20arrangements\%20+\%20NATO\%20declaration.pdf; EU-NATO: The Framework for Permanent Relations and Berlin Plus, http://www.consilium.europa.eu/uedocs/cmsUpload/03-11-11\%20Berlin\%20Plus\%20press\%20note\%20BL.pdf, 29122012
} 
Policy (CSDP) until 2013. ${ }^{75}$ Thus far the goals set by ESDP/ CSDP, which were planned to be implemented by 2003 , later by 2010 , have not been implemented (Headline Goal 2010) ${ }^{76}$. Engagement of each European Union state in military operations further remains a matter of political will. Recently much attention has been devoted to energy security issues on both sides of the Atlantic ${ }^{77}$. There are spheres where transatlantic cooperation is not so smooth; for example, the USA has not granted the visa free regime to some EU countries, such as Poland or Bulgaria.

Though during the US election campaign the theme of Europe was hardly in the picture, the choice of Obama as President on the whole was met favorably in Europe ${ }^{78}$. In the opinion of experts of the European Council on Foreign Relations (ECFR) Obama's words that the USA no longer wanted to be Europe's patron and sought to become its partner would also mean that "the time has come for Europe to grow up" and start to solve the issues of both relations with Russia or Eastern neighbors and become engaged in solving the issues of Syria, Iran, the Near East and other issues ${ }^{79}$. As Jeremy Shapiro and Nick Witney ${ }^{80}$ stated in their study on the relations between the USA and EU, a threat to transatlantic bond rose not because of America's global strategy but because of the fact that Europe itself had not become aware yet of how the world was changing and how the transatlantic bond should change in relation to that ${ }^{81}$. Europe's current relations with the USA are characterized as conflicting and consisting of many identities: bilateral relations of the European states with the USA (which the majority, beginning with the United Kingdom, the Netherlands and ending with the countries of CEE, think to be special); military relations through NATO and developing EU relations with the USA (true, the EU Member States still have a strong feeling of national

\footnotetext{
${ }^{75}$ Frontini A., "A battle against decline? EU defence after the European Council“, 17 December 2012, http://www.epc.eu/pub_details.php?cat_id=4\&pub_id=3198, 23012013

${ }^{76}$ Greco E. et al, eds., "EU crisis management institutions and capabilities in the making", IAI, November 2010, http://www.iai.it/pdf/Quaderni/Quaderni_E_19.pdf; European Parliament, The impact of the financial crisis on European defence, April, 2011,

http://www.europarl.europa.eu/document/activities/cont/201106/20110623ATT22404/20110623ATT2240 4EN.pdf, 10032013

${ }^{77}$ The EU-U.S. Energy Council, December 5, 2012, Joint Press Statement, A 560/12

http://consilium.europa.eu/uedocs/cms_data/docs/pressdata/EN/foraff/134058.pdf, 18012013

${ }^{78}$ Thompson M., "European Leaders: Let's get European Economy Moving“, CNN, http://money.cnn. com/2012/11/07/news/economy/europe-election-economy/index.html, 23012013

${ }^{79}$ Bechev D. et al "Time to Grow-up: what Obama's re-election means for Europe", http://ecfr.eu/content/ entry/time_to_grow_up_what_obamas_re_election_means_for_europe, 18012013

${ }^{80}$ Shapiro J., Witney N., Towards a Post-American Europe: A Power Audit of EU-US Relations, ECFR, http://pasos.org/wp-content/archive/ECFR_EUUSrelations.pdf, 29122012

${ }^{81}$ Ibid. p. 8
} 
sovereignty in the sphere of the security policy too). Stefan Lehne openly says that through the eyes of an outside observer, the block of $28^{82}$ Member States (where all countries formally have equal weight in decision -making process), which unanimously adopts decisions in the sphere of security policy actually has three main players - Germany, France, United Kingdom - upon the behavior of which the position of the entire EU depends to a great extent. The ECFR research carried out all over the European Union denied the prevailing stereotypical opinion about more "European" or more "atlanticist" European states - in the opinion of the majority of the respondents their countries were more than on average committed to both communities. In the opinion of the authors, despite continuing to live with myths, the European Union should be able to formulate and carry out a common foreign policy.

Thus far Europe's unwillingness or inability to speak in a single voice has prevented it from speaking efficiently not only to the USA but also to other powers - China and Russia. In the opinion of Shapiro and Witney, the European states should establish a tradition to discuss various concepts of security in different parts of the Continent inside the European Union. A lack of trust between the old members of the European Union and those that are still regarded as the new ones can be overcome only by open talking of the European States among themselves instead of waiting for Washington's decision on a greater necessity of seeing NATO in the CEE region or their dependence on Russia in the energy sector ${ }^{83}$. The European Union is urged to give the following features to the transatlantic bond: assuming responsibility in the security issues; seeking for agreements/compromises - to do this not only the analysis of the foreign policy problems but also concrete initiatives at the negotiation table are needed; acting on the basis of arguments; choosing a choir rather than solo roles. One of the main reasons identified, which has prevented Europe from making its unanimous voice heard and becoming a significant international player was a lack of a political will and strategic attitude.

As Statkus and Paulauskas have observed, thus far the Lithuanian political elite have followed the (misguided) supposition that strengthening the CFSP (without which the European Union cannot be imagined as a political union) can do harm to the transatlantic bond and they have argued that Lithuania is a part of the identity of this collective subject called Europe ${ }^{84}$, thus it can

\footnotetext{
${ }^{82}$ Since July 1, 2013 after Croatia joins the E.

${ }^{83}$ Ten pat, p. 17

${ }^{84}$ Statkus N., Paulauskas K., Tarp geopolitikos ir postmoderno: kur link sukti Lietuvos užsienio politikai? [In Between Geopolitics and Postmodernism: What Direction the Lithuanian Foreign Policy Take?], 2008 , p. 51
} 
exert influence on its policy. Taking into consideration the present institutional arrangement of the EU, possibilities for Lithuania to influence its policy are limited, however, it can still present its ideas and arguments. For instance, one of the major priorities during Lithuania's presidency in the EU is the Eastern Partnership initiative as a means for creating a more secure and democratic area close to the EU borders.

The thing that is characteristic of Lithuania's institutional structure is that the key role in its foreign policy falls on the Head of the State who decides on the major issues of the foreign policy and, together with the Government, conducts foreign policy. Lithuania is a parliamentary republic (with certain semi-presidential features) that has certain competence (e.g., ratification of international treaties, consideration of other issues of the foreign policy) provided for the Seimas of the Republic of Lithuania too. Hence, when looking for answers to the security issues raised or the explanation of the current situation, it is necessary to take into consideration the institutional structure of the state, perceptions of its political elite, to look for consensus with key social actors about major security issues and necessary measures to be taken.

\section{Conclusions}

Attempts have been made in the article to go back to transatlantic relations and the issues of Lithuania's security, assuming that they are still relevant.

According to the neo-realist theory, small states are especially sensitive to security issues because of their limited power. The foreign policy of small states is primarily influenced by systemic - structural factors and is usually regarded as "adjustment to reality". When looking for security small states usually balance against threats; "soft" power is often emphasized in the global world. With the rise of threats, a state should strengthen the ties of the alliance; to underline interdependence and commitments; to foster a common identity. Small (weak) states can never afford to lose vigilance in security matters or merely enjoy the security provided by a super power.

Lithuania, with its membership of NATO and the EU, is regarded as having essentially solved its security dilema. There are some other features inherent in the foreign policy of small states that are also present in Lithuania's foreign policy: attention to the closest region (e.g. Eastern Partnership); focus on international institutions and norms, emphasis on values. On the other hand, there is a lack of diversification of economic ties (especially, there is a 
problem of higher dependence on a single energy resources supplier). Despite the "securitized" public discourse, Lithuania falls behind other Alliance members in the amount of its expenses allocated to defense. From the point of view of neo-classical realism, this can be explained by intervening unit-level variables - state structures and perceptions of the political elite.

The key factor for foreign policy decision-makers of small states is a reasonable assessment of changes in the international system. Analysts note of a shift from the unipolar to multipolar world because of the rise of the regional powers and economic interdependence. The world nowadays is facing global threats. Accordingly, a strategic change ("pivot to Asia") in the foreign policy of the US, which is considered to be a strategic partner for Lithuania, is being observed. Although commitments to collective defense are persistent, the European allies are encouraged to assume more responsibility in regional security matters. The decrease of the US defense funding and strategic redistribution of it in the world should encourage European countries to invest more in their defense. Measures to strengthen the CSFP will be considered at the highest level by the end of 2013 . The Lithuanian political and academic elite should take these processes into consideration and assess their impact on the security of the country and the region, as well as the best means to address these challenges.

Due to its geopolitical situation, Lithuania is especially keen on the vitality of transatlantic relations. They may be challenged by at least two factors: a need for a more unanimous European attitude and economic-financial constraints on both sides of the Atlantic. Because of the institutional arrangement of the EU, the possibilities for Lithuania to exert influence on the CFSP are limited, however, Lithuania is ready to contribute to a greater security in the region by fostering the Eastern Partnership. Prospects of concluding the Transatlantic Trade and Investment Partnership opens up opportunities for mutual economic recovery and further fostering of social and economic transatlantic ties.

The Copenhagen School believes that security arises from cooperation and a common identity rather than from the ability to concentrate and use power against others. Research shows that the issue of Lithuania's integration into the transatlantic security community is still an unfinished matter.

The aim of the article is to prove that security issues are still of great importance to Lithuania. Their solutions could be as follows:

- to become a reliable, loyal partner to the Alliance not only committing itself to the common policy and strategy of the alliance but also respectively investing in the development of defensive capabilities ; 
- to further deepen Euro-Atlantic integration in the economic-social sphere: to strengthen interdependence reorienting and diversifying its economic-trade relations accordingly; to encourage the development of human relations;

- inside to further strengthen democratic values and institutions;

- in view of the ongoing external processes and with a decade of Lithuania's membership in the Euroatlantic community approaching, a public debate about the changing international environment, Lithuania's place and role in the world, and its understanding of threats and security can be held; it could help to clarify some answers while seeking together with partners on both sides of the Atlantic for common security solutions.

September 2012 - March 2013 